\title{
PEMBUATAN MINUMAN DARI EKSTRAK DAUN PISANG BATU (Musa balbisiana Call) DENGAN PENAMBAHAN FERRO SULFAT
}

\author{
Alsuhendra \\ Ridawati \\ Fakultas Teknik, Universitas Negeri Jakarta \\ E-mail: alsuhendra@gmail.com
}

\begin{abstract}
Chlorophyll was extracted from 'batu' banana leaves and used as raw material for making beverage. The research was conducted at the Laboratory of Food Analysis and Engineering, Faculty of Engineering, State University of Jakarta from April to September 2018. The results of the research showed that chlorophyll of 'batu' banana leaf could be extracted using $0,1 \% \mathrm{NaHCO}_{3}$ solution in a ratio of $1: 5$. The beverage were made using chlorophyll extract with $\mathrm{Fe}^{2+}$ ion 15, 20, and $25 \mathrm{mg} / \mathrm{L}$. By organoleptic test, the panel accepted the beverage between rather like to like for color, aroma, taste, and consistency. The general acceptance of panel on the beverage made by adding $\mathrm{Fe}^{2+}$ ions as much as 25 $\mathrm{mg} / \mathrm{L}$ was higher than others.
\end{abstract}

Keywords: chlorophyll, Fe-pheophytin, banana leaf, beverage

\begin{abstract}
ABSTRAK
Klorofil diekstrak dari daun pisang batu untuk dijadikan sebagai bahan baku pembuatan minuman. Penelitian dilaksanakan di Laboratorium Analisis dan Rekayasa Boga, Fakultas Teknik Universitas Negeri Jakarta dari bulan April sampai September 2018. Hasil penelitian menunjukkan bahwa klorofil daun pisang batu dapat diekstrak menggunakan larutan $\mathrm{NaHCO}_{3} 0,1 \%$ dengan perbandingan 1:5. Minuman dibuat dari ekstrak klorofil daun pisang batu dengan menambahkan ion $\mathrm{Fe}^{2+}$ sebanyak 15,20 , dan $25 \mathrm{mg} / \mathrm{L}$. Berdasarkan hasil uji organoleptik diketahui bahwa minuman tersebut dapat diterima panelis dengan tingkat kesukaan antara agak suka hingga suka untuk aspek warna, aroma, rasa, dan konsistensi. Tingkat penerimaan umum panelis terhadap minuman yang dibuat dengan penambahan ion $\mathrm{Fe}^{2+}$ sebanyak $25 \mathrm{mg} / \mathrm{L}$ lebih tinggi dibandingkan dengan minuman lainnya.

Kata kunci: klorofil, Fe-feofitin, daun pisang, minuman
\end{abstract}

Pisang batu atau pisang klutuk adalah jenis pisang yang banyak dijumpai di Indonesia. Pisang batu memiliki potensi tinggi untuk dikembangkan sebagai bahan baku pembuatan minuman berbasis klorofil. Klorofil dan turunannya adalah pigmen tanaman yang juga telah diketahui berpotensi sebagai antioksidan, antikanker, antiinflamasi, antigenotoksik, antimutagenik, dan antiaterosklerosis (Alsuhendra \& Ridawati, 2016).

Senyawa klorofil dapat diperoleh dari tanaman hijau dan alga. Pada tahun 2004, Alsuhendra telah menganalisis kandungan klorofil dari rumput pahit (Anoxopus compressus [Swartz] Beauv). 
Kandungan klorofil dalam rumput pahit $(2673 \mu \mathrm{g} / \mathrm{g})$ ternyata lebih tinggi dibandingkan beberapa jenis sayuran lain, seperti daun katuk (2202 $\mu \mathrm{g} / \mathrm{g})$, kangkung $(2013,5 \mu \mathrm{g} / \mathrm{g})$, bayam $(1460,9 \mu \mathrm{g} / \mathrm{g})$, caisin atau sawi hijau $(1208,1 \mu \mathrm{g} / \mathrm{g})$, kacang panjang $(224,6 \mu \mathrm{g} / \mathrm{g})$, buncis $(75,4 \mu \mathrm{g} / \mathrm{g})$, dan selada $(631,3$ $\mu \mathrm{g} / \mathrm{g})$.

Alsuhendra \& Ridawati (2016) juga telah mempelajari teknologi proses formulasi minuman dengan menggunakan ekstrak klorofil rumput pahit sebagai bahan baku. Hasil penelitiannya memperlihatkan bahwa ekstrak klorofil rumput pahit dapat diperoleh melalui proses ekstraksi menggunakan larutan $\mathrm{NaHCO}_{3}$ konsentrasi $0,1 \%$ dengan perbandingan antara rumput pahit dan larutan $\mathrm{NaHCO}_{3}$ sebesar 1:5 serta dengan penambahan ion $\mathrm{Cu}^{2+}$ sebanyak $100 \mathrm{mg} / \mathrm{L}$.

Pada penelitian ini dipelajari proses ekstraksi klorofil dari daun pisang batu dan selanjutnya dimodifikasi menjadi senyawa turunannya, yaitu Fe-feofitin. Senyawa Fe-feofitin digunakan sebagai bahan utama pembuatan minuman yang diharapkan dapat meningkatkan kadar hemoglobin darah.

Senyawa Fe-feofitin merupakan salah satu jenis senyawa mengandung zat besi yang mirip dengan besi heme. Jenis besi ini disebut dengan istilah heme tiruan atau heme-mimetic. Nelson \& Ferruzzi (2008) menyatakan bahwa heme-mimetic dibuat dari Fe-feofitin, yaitu suatu senyawa turunan klorofil alami yang dibuat dengan cara mengganti ion $\mathrm{Mg}^{2+}$ pada inti struktur klorofil dengan ion $\mathrm{Fe}^{2+}$ atau ion ferro. Heme-mimetic ini diduga memiliki tingkat penyerapan yang tinggi, sehingga layak digunakan sebagai bahan alternatif untuk pencegahan anemia.

Hasil penelitian Nelson \& Ferruzzi (2008) memperlihatkan bahwa Fe-feofitin memiliki stabilitas pencernaan dan efisiensi miselarisasi (bioaksesibiltas) yang cukup tinggi dengan nilai pemulihan masing-masing sebesar $52,3 \%$ dan $58,7 \%$. Keberadaan Fe-feofitin yang bersifat lipofilik di dalam campuran misel menunjukkan bahwa senyawa ini akan tersedia untuk diserap oleh saluran pencernaan.

Penelitian bertujuan untuk mempelajari proses pembuatan minuman dari ekstrak daun pisang batu yang mengandung klorofil. Hasil penelitian ini diharapkan nilai tambah dari pisang batu semakin meningkat, serta variasi jenis produk alternatif penambah darah yang dapat dikonsumsi masyarakat dalam bentuk minuman semakin besar pula.

\section{METODE}

Penelitian ini dilaksanakan di Laboratorium Rekayasa dan Analisis Boga Fakultas Teknik UNJ dari bulan April hingga Agustus 2018. Bahan utama penelitian ini adalah daun pisang batu yang diperoleh dari pasar Pagi Rawamangun Jakarta Timur, sedangkan bahan lainnya adalah akuades, $\mathrm{NaHCO}_{3}$ (Merck), $\mathrm{FeSO}_{4}$ (Merck), bahan tambahan makanan (Tween 80), madu, dan perisa (pasta) pisang. Bahan-bahan untuk analisis antara lain buffer standar $\mathrm{pH} 4$ dan $\mathrm{pH} 7$ serta aseton (Merck). Beberapa alat penting yang dibutuhkan adalah spektrofotometer UV-VIS, blender, inkubator, refrigerator, neraca analitik, $\mathrm{pH}$ meter, refraktometer, serta peralatan untuk pembuatan produk minuman fungsional, seperti gelas dan sendok.

Kegiatan penelitian meliputi tiga tahap, yaitu: 1) ekstraksi klorofil daun pisang batu, 2) pembuatan minuman dari ekstrak klorofil daun pisang batu, dan 3) penentuan karakteristik kimia dan daya terima panelis terhadap minuman yang dihasilkan.

\section{Ekstraksi Klorofil Daun Pisang Batu}

Klorofil daun pisang batu diekstrak menggunakan larutan $\mathrm{NaHCO}_{3} 0,1 \%(\mathrm{~b} / \mathrm{v})$ sesuai dengan metode yang dikembangkan oleh Rufaida (2008). Hancuran daun pisang yang mengandung klorofil 
disaring dengan kain saring, lalu ekstrak yang diperoleh diinkubasi selama 30 menit dalam inkubator pada suhu $70^{\circ} \mathrm{C}$. Ekstrak klorofil selanjutnya dianalisis kandungan klorofilnya. Ekstrak yang memiliki kadar klorofil tertinggi selanjutnya diberi perlakuan penambahan ion $\mathrm{Fe}^{2+}$ dengan konsentrasi 15, 20 , dan $25 \mathrm{mg} / \mathrm{L}$. Ekstrak klorofil yang telah diberi 3 perlakuan, yaitu penambahan 3 konsentrasi ion $\mathrm{Fe}^{2+}$, selanjutnya didiamkan di dalam lemari pendingin selama 18 jam. Ekstrak ini selanjutnya dapat digunakan sebagai bahan campuran untuk membuat minuman fungsional.

\section{Pembuatan Minuman dari Ekstrak Klorofil}

Minuman dibuat dengan cara mencampurkan ekstrak klorofil yang mengandung ion $\mathrm{Fe}^{2+}$ (Fe-feofitin) dengan bahan tambahan lain, yaitu madu, Tween 80 , dan perisa pisang. Pencarian formula yang tepat dilakukan secara trial and error. Minuman yang dihasilkan selanjutnya ditentukan nilai $\mathrm{pH}$, kadar total padatan terlarut, dan penerimaan panelis menggunakan uji hedonik. Atribut yang dinilai panelis adalah warna, aroma, rasa, dan konsistensi menggunakan 5 skala, yaitu: Sangat suka (skor 5), suka (4), agak suka (3), tidak suka (2), dan sangat tidak suka (1).

\section{HASIL DAN PEMBAHASAN \\ Ekstraksi Klorofil Daun Pisang Batu}

Alsuhendra \& Ridawati (2016) telah mengekstrak klorofil rumput pahit menggunakan 4 konsentrasi larutan sodium bikarbonat $\left(\mathrm{NaHCO}_{3}\right.$ ), yaitu 0 (nol), 0,1\%, 0,3\%, dan 0,5\%. Penggunaan 4 konsentrasi ini dimaksudkan untuk menentukan kondisi optimal dari proses ekstraksi, sehingga ekstrak yang diperoleh memiliki kandungan klorofil tinggi. Berdasarkan karakteristik ekstrak klorofil yang telah diteliti oleh Alsuhendra \& Ridawati (2016), yaitu kadar klorofil, ekstraksi menggunakan larutan $\mathrm{NaHCO}_{3}$ 0,1\% memberikan kadar klorofil tertinggi dari ekstrak dibandingkan dengan konsentrasi lainnya. Karena itu, pada penelitian ini, ekstraksi klorofil daun pisang batu dilakukan menggunakan larutan $\mathrm{NaHCO}_{3}$ dengan konsentrasi $0,1 \%$.

Menurut Ernaini, Supriadi, \& Rinto (2012), penggunaan pelarut yang bersifat basa, seperti $\mathrm{NaHCO}_{3}$, dapat mencegah degradasi klorofil menjadi feofitin yang berwarna hijau kecoklatan. Selain $\mathrm{NaHCO}_{3}$, pelarut lain yang bersifat basa dan dapat digunakan untuk mengekstraksi klorofil adalah $\mathrm{MgCO}_{3}$ (Hutajulu, Hartanto, \& Subagia, 2008). Dalam hal ini, klorofil yang berada dalam lingkungan basa bersifat lebih stabil, sehingga dapat mencegah terjadinya reaksi pembentukan feofitin, karena ion magnesium yang terdapat di dalam struktur tetrapirol klorofil tidak lepas dan digantikan oleh ion hidrogen.

Pada penelitian ini, kadar klorofil total ekstrak daun pisang batu adalah $62,25 \pm 12,2 \mathrm{mg} / \mathrm{L}$, sedangkan kadar klorofil a dan b secara berturut-turut adalah 25,84 \pm 0,83 dan 36,43 \pm 13,06 mg/L (Gambar 1). Kadar klorofil ekstrak daun pisang batu lebih tinggi dibandingkan dengan ekstrak rumput pahit, yaitu 5,02 mg/L, (Alsuhendra \& Ridawati 2016) dan ekstrak air daun kiambang, yaitu 16,435 mg/L (Ernaini, et al., 2012). 


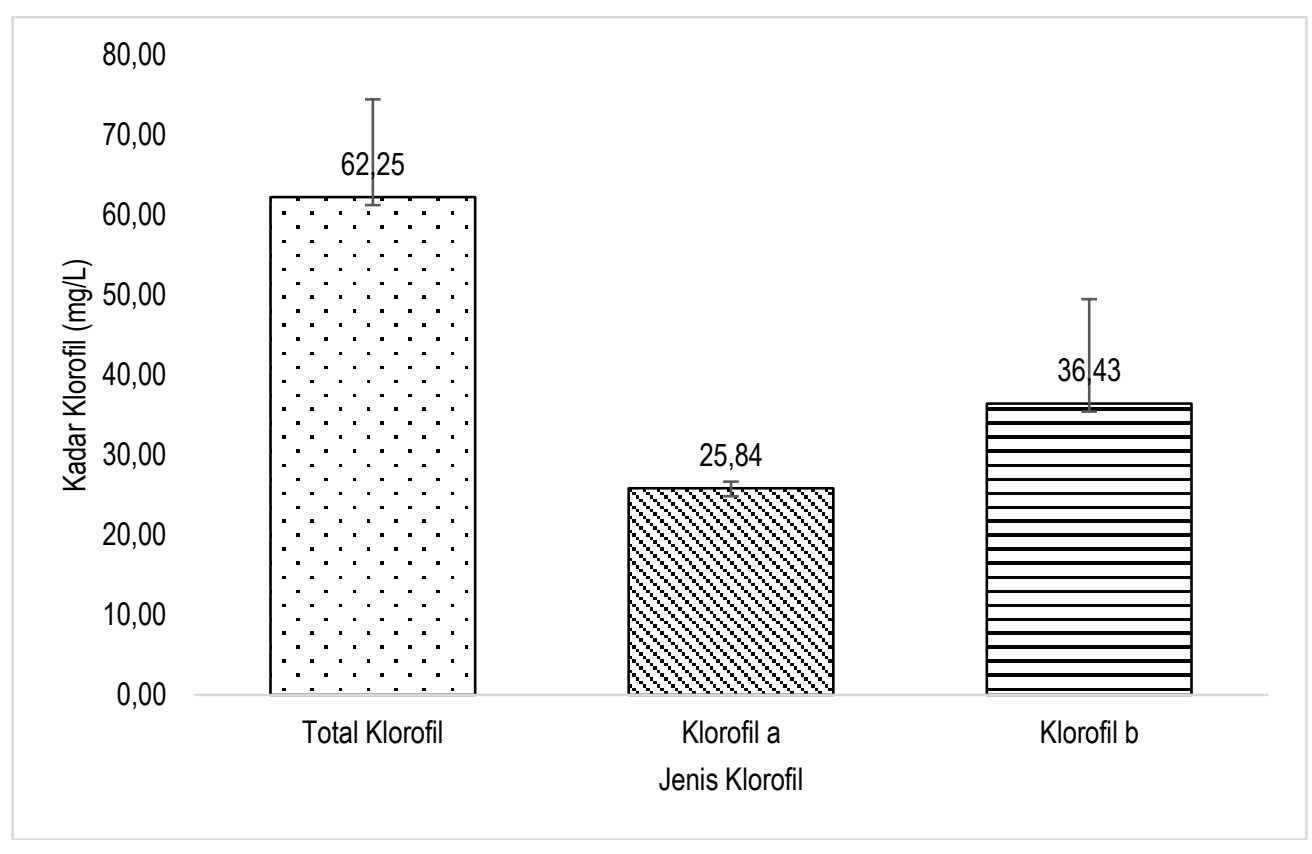

Gambar 1. Kadar klorofil ekstrak daun pisang batu

\section{Penambahan Ion $\mathrm{Fe}^{2+}$ pada Ekstrak Klorofil Daun Pisang Batu}

Untuk mendapatkan senyawa turunan klorofil yang mengandung ion $\mathrm{Fe}^{2+}$, pada penelitian ini telah dilakukan penambahan ion $\mathrm{Fe}^{2+}$ yang berasal dari senyawa ferro sulfat $\left(\mathrm{FeSO}_{4}\right)$. Ferro sulfat merupakan salah satu sumber ion $\mathrm{Fe}^{2+}$ yang banyak digunakan dalam bidang pangan karena larut dalam air dan mudah didapatkan dengan harga relatif murah (Paramastuti \& Rustanti, 2016). Selain itu, ferro sulfat adalah jenis senyawa besi yang memiliki ketersediaan biologi yang tinggi (Asterini, Sugiyono, \& Prangdimurti, 2016).

Senyawa $\mathrm{FeSO}_{4}$ memiliki warna merah dan rasa khas besi, sehingga jika senyawa ini terlalu banyak digunakan dalam pembuatan turunan klorofil, berupa Fe-feofitin, maka ekstrak klorofil akan memiliki warna yang gelap dengan rasa besi yang kuat. Karena itu, banyaknya ion $\mathrm{Fe}^{2+}$ yang ditambahkan ke dalam ekstrak klorofil daun pisang ditetapkan tidak terlalu tinggi, yaitu 15, 20, dan 25 $\mathrm{mg} / \mathrm{L}$. Penambahan ion $\mathrm{Fe}^{2+}$ di atas $25 \mathrm{mg} / \mathrm{L}$ memberikan rasa besi yang kuat pada minuman.

\section{Pembuatan Minuman dari Ekstrak Fe-Feofitin}

Ekstrak Fe-feofitin daun pisang batu yang diperoleh dijadikan sebagai bahan baku utama pembuatan minuman. Untuk mendapatkan minuman yang homogen, ke dalam ekstrak Fe-feofitin ditambahkan penstabil Tween 80 , sedangkan untuk mendapatkan citarasa yang disukai panelis dilakukan penambahan pemanis berupa madu dan perisa pisang. Penambahan perisa pisang dapat menutup rasa dan aroma khas daun pisang pada ekstrak.

Pada pembuatan minuman, penambahan ion $\mathrm{Fe}^{2+}$ ke dalam ekstrak klorofil harus mempertimbangkan warna dan rasa dari minuman. Semakin tinggi konsentrasi ion $\mathrm{Fe}^{2+}$ yang ditambahkan, rasa besi pada minuman akan semakin kuat serta warna minuman akan semakin gelap. Karena itu, pada penelitian, jumlah ion $\mathrm{Fe}^{2+}$ yang ditambahkan tidak terlalu banyak, yaitu hanya 15, 20, dan 25 mg/L. Minuman yang dihasilkan dapat dilihat pada Gambar 2. 


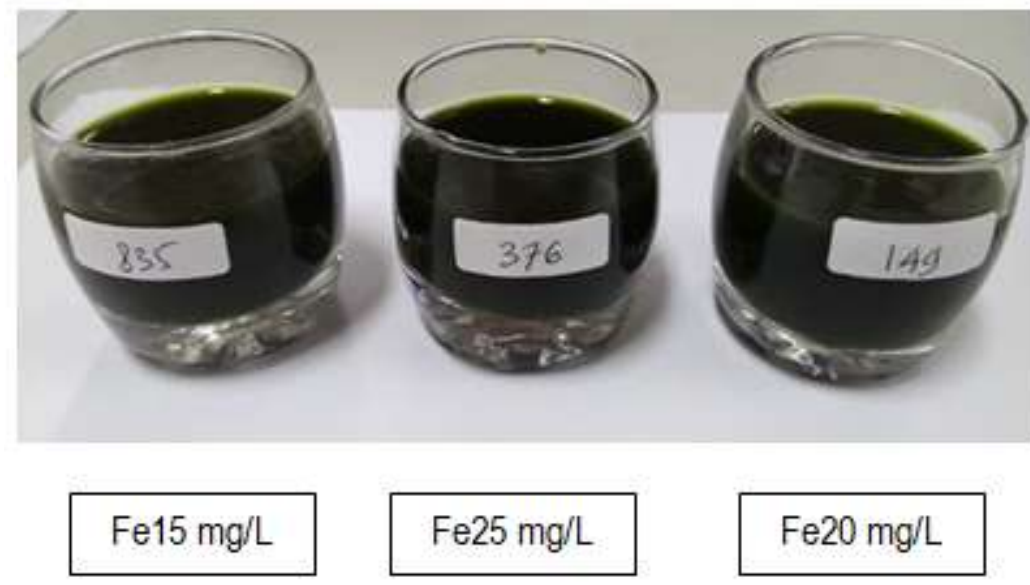

Gambar 2. Minuman Fe-Feofitin dari daun pisang batu

\section{Karakterisasi Mutu dan Daya Terima Minuman Fungsional}

Minuman Fe-feofitin daun pisang batu memiliki beberapa karakteristik sebagai berikut.

\section{1) Warna}

Semua minuman memiliki warna hijau pekat karena ekstraksi klorofil dilakukan dengan menggunakan larutan $\mathrm{NaHCO}_{3}$ dengan perbandingan daun pisang dan larutan sebesar 1:5. Penambahan ion $\mathrm{Fe}^{2+}$ tidak mempengaruhi warna minuman.

2) Aroma

Pada pembuatan minuman ini dilakukan penambahan perisa pisang ambon agar aroma khas daun pisang dapat ditutupi. Semua minuman memiliki aroma pisang yang kuat. Tidak terdapat pengaruh penambahan ion $\mathrm{Fe}^{2+}$ terhadap aroma minuman. Ini berarti penambahan perisa dapat menutupi aroma khas zat besi yang berasal dari senyawa $\mathrm{FeSO}_{4}$ yang digunakan sebagai sumber ion $\mathrm{Fe}^{2+}$.

3) Rasa

Penambahan zat besi sebanyak $15 \mathrm{mg} / \mathrm{L}$ pada ekstrak klorofil tidak mempengaruhi rasa minuman. Minuman yang dihasilkan memiliki rasa manis dan sedikit rasa daun pisang. Rasa manis diperoleh dari penambahan madu sebanyak $10 \%$ (b/v). Hal yang sama juga ditemukan pada minuman yang ditambah dengan ion $\mathrm{Fe}^{2+}$ sebanyak $20 \mathrm{mg} / \mathrm{L}$ dan $25 \mathrm{mg} / \mathrm{L}$.

4) Konsistensi Semua minuman memiliki konsistensi cair. Penambahan ion $\mathrm{Fe}^{2+}$ dalam konsentrasi berbeda tidak memberikan pengaruh terhadap konsistensi minuman.

Selain mutu, minuman Fe-feofitin daun pisang batu juga dipelajari penerimaannya oleh panelis tidak terlatih. Pada penelitian ini, panelis yang digunakan adalah para karyawan yang ada di Fakultas Teknik UNJ. Hasil penilaian daya terima panelis dijelaskan di bawah ini.

1) Penerimaan terhadap warna

Skala penerimaan untuk rata-rata penerimaan panelis terhadap warna minuman berkisar antara 3,4-3,9 (Gambar 3). Penerimaan dengan nilai 3,4 \pm 0,5 (agak suka) diberikan pada minuman yang ditambah dengan ion $\mathrm{Fe}^{2+}$ sebanyak $20 \mathrm{mg} / \mathrm{L}$, sedangkan penerimaan dengan nilai 3,5 \pm 
1,1 (antara agak suka hingga suka) diberikan pada minuman dengan perlakuan penambahan ion $\mathrm{Fe}^{2+}$ sebanyak $25 \mathrm{mg} / \mathrm{L}$. Minuman dengan penambahan ion $\mathrm{Fe}^{2+}$ sebanyak $25 \mathrm{mg} / \mathrm{L}$ memiliki penerimaan terhadap warna mendekati suka $(3,9 \pm 0,8)$.

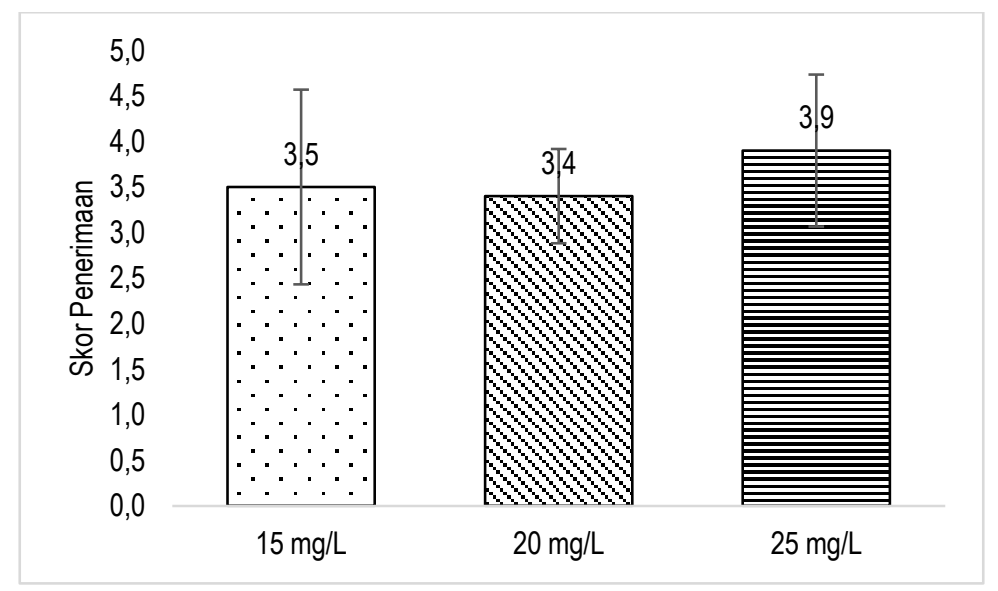

Gambar 3. Rata-rata skor penerimaan warna minuman Fe-Feofitin daun pisang batu

2) Penerimaan terhadap aroma

Tingkat penerimaan panelis terhadap aroma minuman Fe-feofitin daun pisang batu (Gambar 4), berada pada kisaran antara agak suka hingga suka $(3,6-3,9)$. Ini menunjukkan bahwa perbedaan penambahan ion $\mathrm{Fe}^{2+}$ tidak terlalu berpengaruh terhadap aroma minuman.

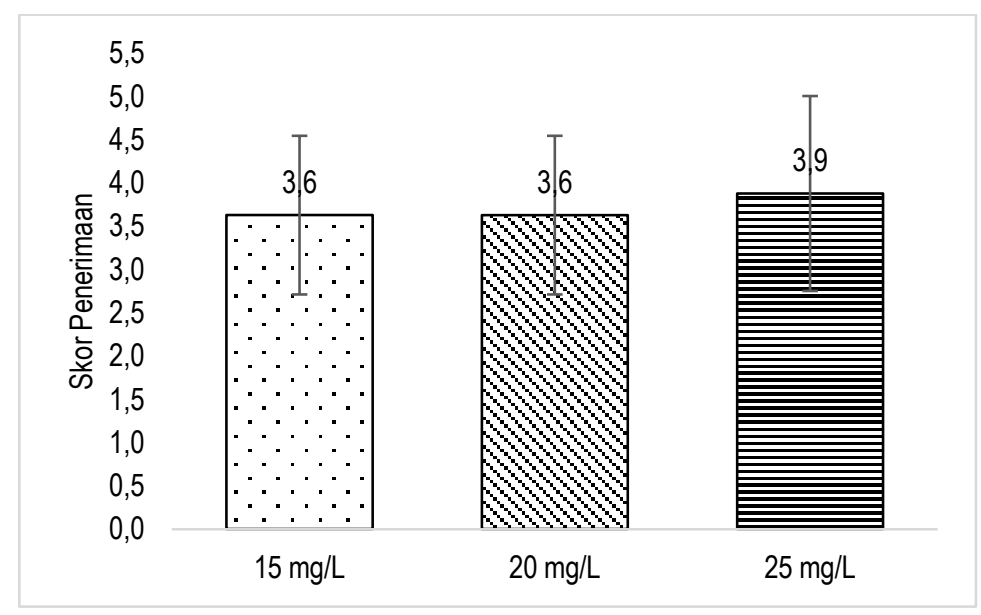

Gambar 4. Rata-rata skor penerimaan aroma minuman Fe-Feofitin daun pisang batu

\section{3) Penerimaan terhadap rasa}

Penambahan ion $\mathrm{Fe}^{2+}$ terlihat memberikan pengaruh nyata terhadap rasa minuman $\mathrm{Fe}$-feofitin yang dihasilkan (Gambar 5). Panelis memberikan penilaian 3,5 1,4 atau antara agak suka hingga suka untuk minuman dengan perlakuan $25 \mathrm{mg} / \mathrm{L}$, sedangkan minuman dengan penambahan ion $\mathrm{Fe}^{2+}$ sebanyak $15 \mathrm{mg} / \mathrm{L}$ mendapatkan penilaian 2,9 $\pm 1,1$ atau mendekati agak 
suka oleh panelis. Terdapat kecenderungan bahwa semakin tinggi tingkat penambahan ion $\mathrm{Fe}^{2+}$, semakin tinggi pula tingkat kesukaan panelis terhadap rasa minuman.

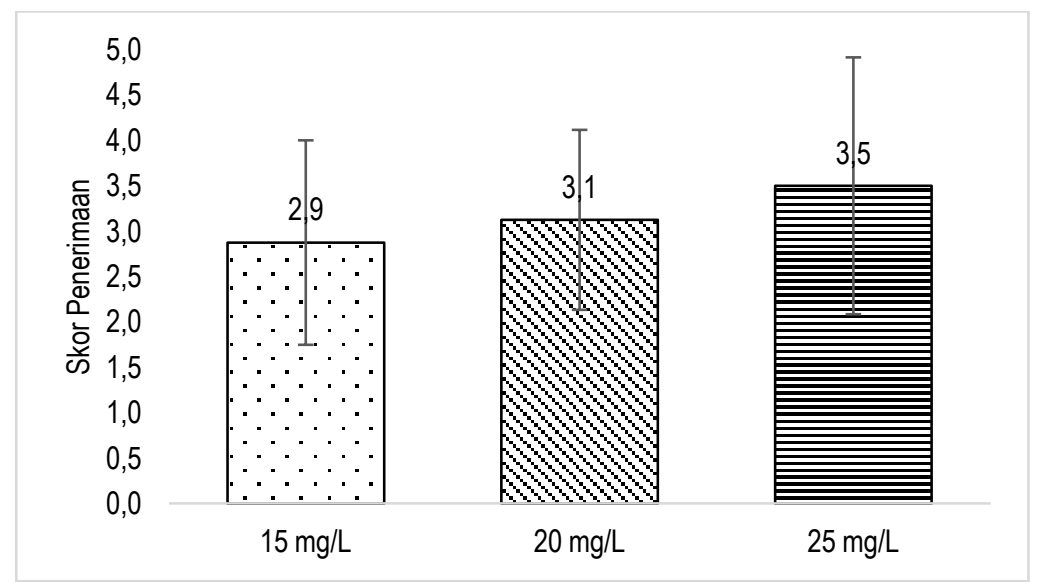

Gambar 5. Rata-rata skor penerimaan rasa minuman Fe-Feofitin daun pisang batu

4) Penerimaan terhadap konsistensi

Sebagaimana halnya dengan peneriman terhadap rasa minuman, panelis memberikan penilaian yang cenderung meningkat pada minuman seiring dengan banyaknya jumlah ion $\mathrm{Fe}^{2+}$ yang ditambahkan. Pada Gambar 6 dapat dilihat bahwa konsistensi minuman yang mendapatkan penilaian paling tinggi oleh panelis adalah minuman dengan penambahan ion $\mathrm{Fe}^{2+}$ sebesar 25 $\mathrm{mg} / \mathrm{L}$, yaitu mendekati suka.

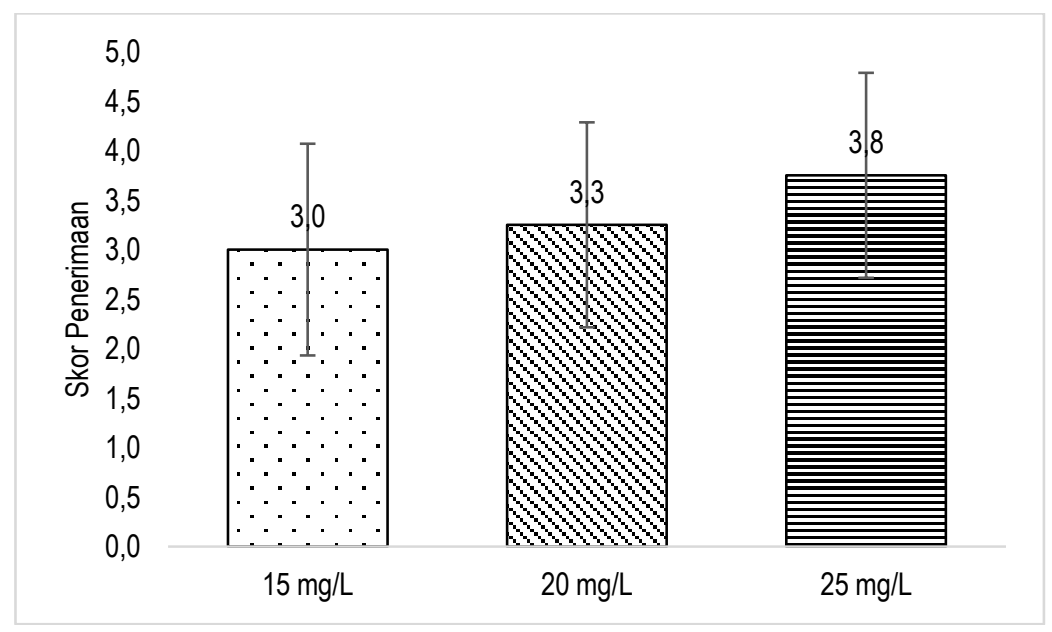

Gambar 6. Rata-rata skor penerimaan konsistensi minuman Fe-Feofitin daun pisang batu

Selain daya terima, minuman Fe-feofitin daun pisang batu juga dipelajari beberapa sifat kimianya, antara lain nilai pH dan kadar gula. 


\section{a) Nilai $\mathrm{pH}$}

Nilai pH merupakan salah satu parameter penting sebuah minuman karena pH minuman dapat mempengaruhi sistem metabolisme dalam tubuh manusia. Minuman dengan $\mathrm{pH}$ yang terlalu rendah dapat menyebabkan proses demineralisasi enamel gigi atau dapat menurunkan kekerasan permukaan enamel gigi (Prasetyo, 2005).

Pada penelitian ini, minuman Fe-feofitin daun pisang batu dapat dinyatakan bersifat basa karena memiliki pH antara 8,6 hingga 8,7 (Gambar 7). Nilai pH ketiga minuman relatif sama. Ini berarti bahwa penambahan ion $\mathrm{Fe}^{2+}$ tidak berpengaruh terhadap nilai $\mathrm{pH}$ minuman.

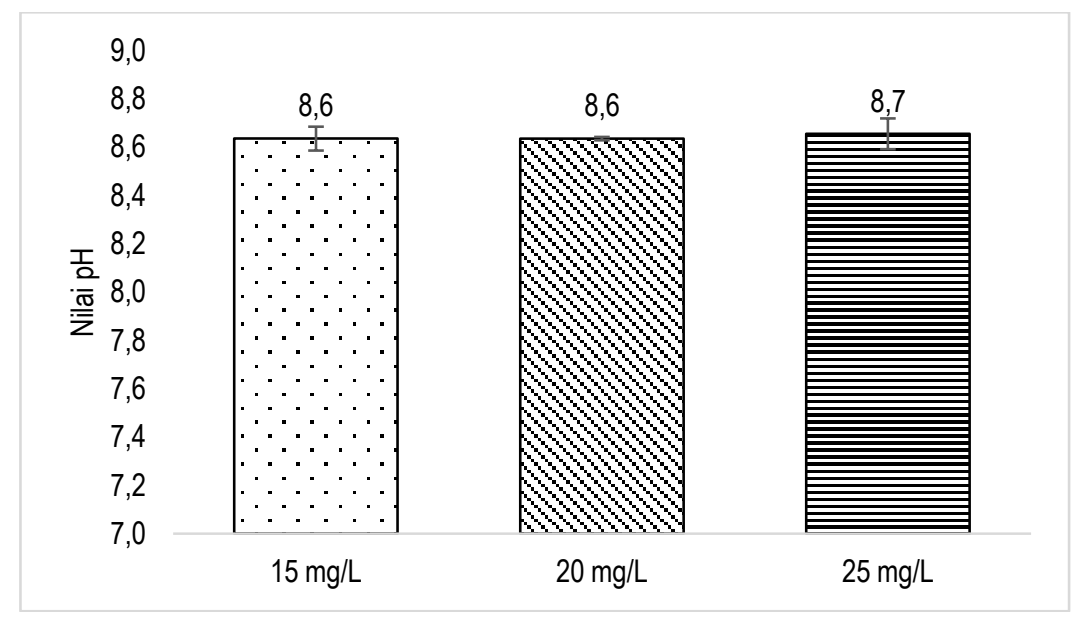

Gambar 7. Nilai pH minuman fungsional

\section{b) Kadar Total Padatan Terlarut (Gula)}

Kadar total padatan terlarut menunjukkan banyaknya bahan terlarut yang terdapat dalam minuman. Menurut Ismawati, Nurwantoro, \& Pramono (2016), komponen padatan terlarut terdiri atas total gula, pigmen, asam-asam organik, dan protein.

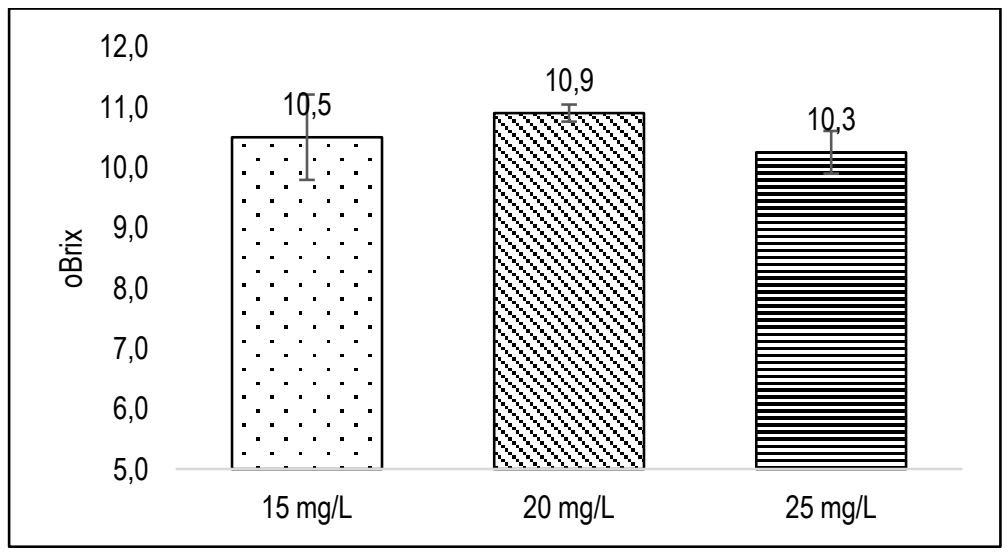

Gambar 8. Kadar gula minuman 
Pada penelitian ini, minuman dibuat dengan menambahkan madu sebanyak $10 \%$. Setelah dianalisis dengan alat refraktometer, nilai kadar total padatan terlarut atau kadar gula minuman Fefeofitin daun pisang berkisar adalah $10,5 \pm 0,71^{\circ}$ Brix untuk minuman dengan penambahan ion $\mathrm{Fe}^{2+}$ sebesar $15 \mathrm{mg} / \mathrm{L}, 10,9 \pm 0,14{ }^{\circ}$ Brix untuk $20 \mathrm{mg} / \mathrm{L}$, dan 10,3 $\pm 0,35^{\circ}$ Brix untuk $25 \mathrm{mg} / \mathrm{L}$ (Gambar 8 ). Penambahan ion $\mathrm{Fe}^{2+}$ dalam jumlah berbeda ternyata tidak memberikan pengaruh nyata terhadap kadar total padatan terlarut minuman.

\section{SIMPULAN}

Ekstraksi klorofil daun pisang batu dapat dilakukan dengan menggunakan larutan $\mathrm{NaHCO}_{3}$ $0,1 \%$ dengan perbandingan antara daun pisang dan larutan $\mathrm{NaHCO}_{3}$ sebesar 1:5. Ekstrak klorofil daun pisang batu dapat dibuat menjadi minuman dengan menambahkan ion $\mathrm{Fe}^{2+}$ sebanyak 15, 20 , dan $25 \mathrm{mg} / \mathrm{L}$. Minuman tersebut dapat diterima panelis karena dari hasil uji organoleptik, panelis memberikan penilaian rata-rata antara agak suka hingga suka untuk aspek warna, aroma, rasa, dan konsistensi. Tingkat penerimaan umum panelis terhadap minuman yang dibuat dengan penambahan ion $\mathrm{Fe}^{2+}$ sebanyak $25 \mathrm{mg} / \mathrm{L}$ lebih tinggi dibandingkan dengan minuman lainnya.

\section{REFERENSI}

Alsuhendra \& Ridawati. (2016). Formulasi produk minuman fungsional berbasis klorofil dari rumput pahit (Anoxopus compressus [Scwartz] Beauv) dan Antosianin dari Ubi Jalar Ungu (Ipomoea batatas L.). Fakultas Teknik Universitas Negeri Jakarta.

Alsuhendra. (2004). Daya antiaterosklerosis Zn-turunan klorofil dari daun singkong. Disertasi yang tidak dipublikasikan. Sekolah Pascasarjana IPB, Bogor.

Asterini, Sugiyono, W., \& Prangdimurti, E. (2016). Peluang aplikasi ikroenkapsulat vitamin A dan zat besi sebagai fortifikan. Pangan, 25 (1), 51- 60.

Ernaini, Y., Supriadi, A. \& Rinto. (2012). Pengaruh jenis pelarut terhadap klorofil dan senyawa fitokimia daun kiambang (Salvinia Molesta Mitchell) dari perairan rawa. Unsri. Jurnal FishtecH, 1 (1).

Hutajulu, T.F., Hartanto, \& Subagia. (2008). Proses ekstraksi zat warna hijau khlorofil alami untuk pangan dan karakteristiknya. J Riset Industri, 2(1), 44-45.

Ismawati, N., Nurwantoro, \& Pramono. Y.B. (2016). Nilai pH, total padatan terlarut, dan sifat sensoris yoghurt dengan penambahan ekstrak bit (Beta vulgaris L.). Jurnal Aplikasi Teknologi Pangan, 5 (3), 89-93.

Nelson, RE \& Ferruzzi. M.G. (2008). Synthesis and bioaccessibility of Fe-pheophytin derivatives from crude spinach extract. J. Food Sci., 73(5), 86-91.

Paramastuti, R. \& Rustanti, N. (2016). Pengaruh fortifikan Fe terhadap kadar Fe, total BAL, pH dan organoleptik yogurt sinbiotik jelly drink yang difortifikasi vitamin A. Journal of Nutrition College, 5(4), 539-545.

Prasetyo, E.A. (2005). Keasaman minuman ringan menurunkan kekerasan permukaan gigi. Maj. Ked. Gigi. (Dent. J.), 38(2), 60-63.

Rufaida, R. (2008). Pembuatan minuman klorofil daun suji (Pleomele angustifolia N.E. Brown) dan evaluasi mutunya selama penyimpanan. Skripsi IPB, Bogor. 